\title{
Optimization of Extracellular Lipase Production by Penicillium chrysogenum Using Factorial Design
}

\author{
Mona Sayed Shafei ${ }^{1 \star}$, Tamer Adel Mohamed $^{2}$ and Ibrahim Shaban Abd Elsalam ${ }^{1}$ \\ ${ }^{1}$ Chemistry of Natural and Microbial Products Department, National Research Center, Cairo, Egypt \\ ${ }^{2}$ Mechanical Engineering Department, The British University in Egypt, Cairo, Egypt \\ E-mail:mona_sayed@hotmail.com
}

Received 28 June 2010; received in revised form 12 September 2010; accepted 22 September 2010

\begin{abstract}
The effect of oxygen on lipase production by Penicillium chrysogenum was studied under two operating modes, controlled aeration rate tested and controlled agitation at dissolved oxygen concentration (DO) $1.00 \mathrm{vvm}$. Lipase production and cell dry weight were tested in a stirred batch fermenter $5 \mathrm{~L}$. Improvement in oxygen transfer rate (OTR) either by aeration or agitation resulted in an increase in lipase production. Growth curves and lipase activities of P.chrysogenum were examined at agitation rates $(200,400,600 \mathrm{rpm})$, aeration rates $(2,4 \mathrm{vvm})$ at different fermentation periods $(24,48,72,96,120$ h). Response Surface Methodology (RSM) using Design Expert software was used to study the effect of aeration, agitation, and fermentation time on lipase activity and cell dry weight. These factors were analyzed using $2^{1} .3^{2}$ level factorial design. An optimal set of conditions that maximize lipase production: ( $2 \mathrm{vvm}$ aeration; $600 \mathrm{rpm}$ agitation after $72 \mathrm{~h}$ ) was obtained. The maximum lipase activity obtained was $240 \mathrm{U} / \mathrm{mL}$. Beside lipase activity, this paper also studies the optimal combination of the controllable factors (aeration; agitation and fermentation time) that will maximize the cell dry weight.
\end{abstract}

Keywords: lipase activity, optimization, fermentation, factorial design, Design-Expert software.

\section{INTRODUCTION}

Lipases (EC 3.1.1.3) are enzymes, the biological function of which is to catalyze the hydrolysis of tri-acyl glycerol to fatty acids, mono- and di-acylglycerols and glycerol. Lipases act specifically at oil/water interfaces (Cihangir and Sarikaya, 2004; Javed et al., 2007). Lipolytic enzymes can be found in animals, plants and microorganisms (Kamimura et al., 2000; Burkert et al., 2004). They form an important enzyme group due to their remarkable levels of activity and stability in both aqueous and non-aqueous media, which enables several reactions catalysis such as acidolysis, alcoholysis, aminolysis, esterification and transesterification. Lipases also show unique properties of chemo-, regio-and enantio- selectivity (Gutarra et al., 2009).

The interest in microbial lipase production has increased in the last decades, because of its large potential in industrial applications as additives in food, fine chemical, detergents, waste water treatment, cosmetics, pharmaceuticals, leather, and medicines (Kamini et al., 2000; Sharma et al., 2001).

Microbial lipase fermentations are affected by $\mathrm{pH}$ temperature, medium composition, aeration, agitation etc (Chen et al., 1999). It was reported that the presence of air was essential for lipase production by Staphylococcus aureus (Vadehra and Harmos, 1969) and Pseudomonas putida (Lee and Rhee, 1993). It was previously summarized, that improvements in aeration of liquid by agitation or air sparging is beneficial for lipase production in all cases for single cell organisms and in most cases for filamentous moulds (Frost and Moss, 1987).

Most lipases used in biotechnological applications are produced by fungi and bacteria. Filamentous fungi are interesting sources of lipases because they produce extracellular enzymes (Hölker et al., 2004). As in any application that demands high enzyme quantities such as treatment of oily wastewater and biodiesel production, lipase utilization depends on the reduction of its costs to become economically feasible (Cammarota and Freire, 2006). For the optimization, RSM was used as a tool since it enables the evaluation of multiple parameters alone or in combination on response variables (Mutalik et al., 2008).It is also a statistical technique useful for designing experiments, building models and analyzing the effects of independent variables (Garrido-Vidal et al., 2003; Nemukula et al., 2009).

Our objectives were to better understand the relationship between the factors (aeration, agitation and time) and the response values (lipase activity and cell dry weight) and to determine the optimal conditions that maximize lipase production/cell dry weight. 


\section{MATERIALS AND METHODS}

\section{Microorganism and culture conditions}

Penicillium chrysogenum used in the present work was kindly obtained from Chemistry of Natural and Microbial Products Dept., National Research Center, Cairo, Egypt. The slants of $P$. chrysogenum were incubated on potatodextrose agar medium (PDA) at $30{ }^{\circ} \mathrm{C}$ for 7 days.

\section{Lipase production}

$P$. chrysogenum was cultured on the following medium ( $\mathrm{g} / \mathrm{L}$ in distilled water): yeast extract 5 ; olive oil $10 ; \mathrm{KNO}_{3} 2$; $\mathrm{MgSO}_{4} \cdot 7 \mathrm{H}_{2} \mathrm{O} \quad 0.5 ; \mathrm{K}_{2} \mathrm{HPO}_{4} \quad 1 ; \mathrm{ZnSO}_{4} \cdot 7 \mathrm{H}_{2} \mathrm{O} \quad 0.44 ;$ $\mathrm{FeSO}_{4} \cdot 7 \mathrm{H}_{2} \mathrm{O}$ 1.1; $\mathrm{MnSO}_{4} \cdot 7 \mathrm{H}_{2} \mathrm{O} 0.2 ;\left(\mathrm{NH}_{4}\right)_{2} \mathrm{SO}_{4} 10$ at $\mathrm{pH}$ 7.0 using phosphate buffer (Lima et al., 2003).

\section{Fermenter culture}

Fermenter experiments were carried out in a $5 \mathrm{~L}$ jar fermenter (Braun biotech, International microdcu 200) which was adopted for bench-scale cultivation under the following conditions: the inoculum was prepared in 5 Erlenmyer flasks $250 \mathrm{~mL}$ each with $100 \mathrm{~mL}$ medium. The cultures were inoculated with $4 \mathrm{~mL}$ of spores suspension $\left(10^{8} \mathrm{spores} / \mathrm{mL}\right)$ and the flasks were agitated at $120 \mathrm{rpm}$ at $30{ }^{\circ} \mathrm{C}$. After $48 \mathrm{~h}$, the whole volume was transferred into the fermenter. The submerged cultivation was performed in $5 \mathrm{~L}$ glass fermentor with working volume $3 \mathrm{~L}$ and the $\mathrm{pH}$ was automatically controlled at $\mathrm{pH} 7.0$ using $0.1 \mathrm{~N} \mathrm{NaOH}$ or $0.1 \mathrm{~N} \mathrm{HCl}$. The dissolved oxygen concentration (DO) was maintained at $1.00 \mathrm{vvm}$. Samples $(25 \mathrm{~mL})$ were daily collected for analysis. The experiments were repeated with variously stirred agitation speed (200; $400 ; 600 \mathrm{rpm})$, aeration (2.0; $4.0 \mathrm{vvm})$ during different fermentation time $(24,48,72,96,120 \mathrm{~h})$ corresponding to the growth phase of the microorganism.

\section{Lipase activity}

Lipase activity was determined using an emulsion of $10 \%$ olive oil in $10 \%$ gum Arabic. The emulsion was prepared by treating the mixture of olive oil and gum Arabic solution in a top drive homogenizer for $10 \mathrm{~min}$. The reaction mixture contained $3 \mathrm{~mL}$ of the substrate, $2.5 \mathrm{~mL}$ of deionized water, $1 \mathrm{~mL}$ of $0.1 \mathrm{M}$ Tris-HCl buffer $(\mathrm{pH} 7.5)$ and $1 \mathrm{~mL}$ of culture filtrate. The mixture was incubated for $2 \mathrm{~h}$ at $35^{\circ} \mathrm{C}$ in shaking water bath after which $10 \mathrm{~mL}$ of $99 \%$ acetone (absolute) was added. The resulting mixture was then titrated against $0.5 \mathrm{~N} \mathrm{NaOH}$ using thymolphethalein indicator. Blanks were obtained by boiling the culture filtrate. The lipase activity was defined as that produces $1 \mu$ mole of free fatty acids under assayed conditions (Parry et al., 1966).

\section{Biomass estimation}

The mycelial biomass obtained after growth, was separated by filtration, washed by distilled water, dried in an oven $60^{\circ} \mathrm{C}$ and reweighed till constant weight.

Table 1: Factors examined as independent variables effecting lipase production and cell dry weight by P.chysogenum and their levels.

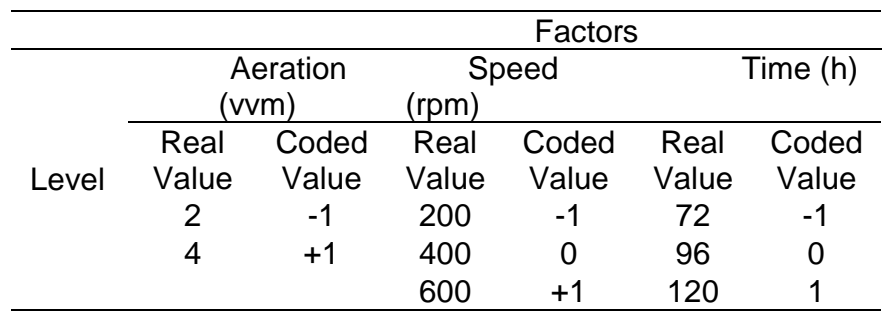

Table 2: Table 2: The experimental design for 3 variables and its results on the responses (lipase production and cell dry weight).

\begin{tabular}{llllll}
\hline $\begin{array}{l}\text { No. } \\
\text { trial }\end{array}$ & $\begin{array}{l}\text { Aeration } \\
(\mathrm{vvm})\end{array}$ & $\begin{array}{l}\text { Speed } \\
(\mathrm{rpm})\end{array}$ & $\begin{array}{l}\text { Time } \\
(\mathrm{h})\end{array}$ & $\begin{array}{l}\text { Lipase } \\
\text { activity } \\
(\mathrm{U} / \mathrm{mL})\end{array}$ & $\begin{array}{l}\text { Cell dry } \\
\text { weight } \\
(\mathrm{g} / 100 \\
\mathrm{mL})\end{array}$ \\
\hline 1 & -1 & -1 & -1 & 96.67 & 3.126 \\
2 & -1 & -1 & 0 & 140 & 3.345 \\
3 & -1 & -1 & +1 & 80 & 3.382 \\
& & & & & \\
4 & +1 & -1 & -1 & 101.667 & 3.704 \\
5 & +1 & -1 & 0 & 160 & 3.86 \\
6 & +1 & -1 & +1 & 120 & 3.57 \\
7 & -1 & 0 & -1 & 175 & 3.990 \\
8 & -1 & 0 & 0 & 155 & 3.954 \\
9 & -1 & 0 & +1 & 110 & 3.954 \\
& & & & & \\
10 & +1 & 0 & -1 & 205 & 4.593 \\
11 & +1 & 0 & 0 & 180 & 4.408 \\
12 & +1 & 0 & +1 & 161.667 & 4.600 \\
& & & & & \\
13 & -1 & +1 & -1 & 240 & 4.974 \\
14 & -1 & +1 & 0 & 200 & 4.755 \\
15 & -1 & +1 & +1 & 170 & 4.810 \\
& & & & & \\
16 & +1 & +1 & -1 & 138.33 & 3.776 \\
17 & +1 & +1 & 0 & 95 & 3.50 \\
18 & +1 & +1 & +1 & 80 & 3.631 \\
\hline & & & & & \\
\hline
\end{tabular}

\section{Factorial design}

A general factorial design $2^{1} \cdot 3^{2}$ with three controllable and two response factors was studied resulting in 18 run each replicated three times to estimate the experimental error. The aim of the study was to find the optimum fermentation time that maximizes the lipase activity and the cell dry 
weight. The aeration was tested at two levels ( 2 and 4 vvm) while the speed was tested at three levels $(200,400$ and $600 \mathrm{rpm})$ at 3 fermentation times $(72,96$ and $120 \mathrm{~h}$ ). The response factors were the lipase activity $(\mathrm{U} / \mathrm{mL})$ and the cell dry weight $(g / 100)$. The statistical analysis of the observed data was performed using the Design Expect software. The test factors and their levels are shown in Table 1, followed by the experimental design and response values in Table 2 .

\section{RESULTS AND DISCUSSION}

\section{P. chrysogenum lipase production and cell dry weight}

The effect of aeration, speed and fermentation time on lipase production and cell dry weight of $P$. chrysogenum were tested. The experiments were carried out in $5 \mathrm{~L}$ fermenter with working volume $3.0 \mathrm{~L}$. Lipase activity and the corresponding growth curve were studied at aeration (2, 4 vvm) agitation $(200,400,600$, rpm) at different incubation periods (Figures 1 and 2).

Figure 1 shows the growth curve and the time course at different agitation speeds (200, 400, $600 \mathrm{rpm})$ at controlled aeration $2 \mathrm{vvm}$. The lipase production started from early stages and reached maximum in late log phase after $72 \mathrm{~h}$ for both agitation speeds 400 and $600 \mathrm{rpm}$. It

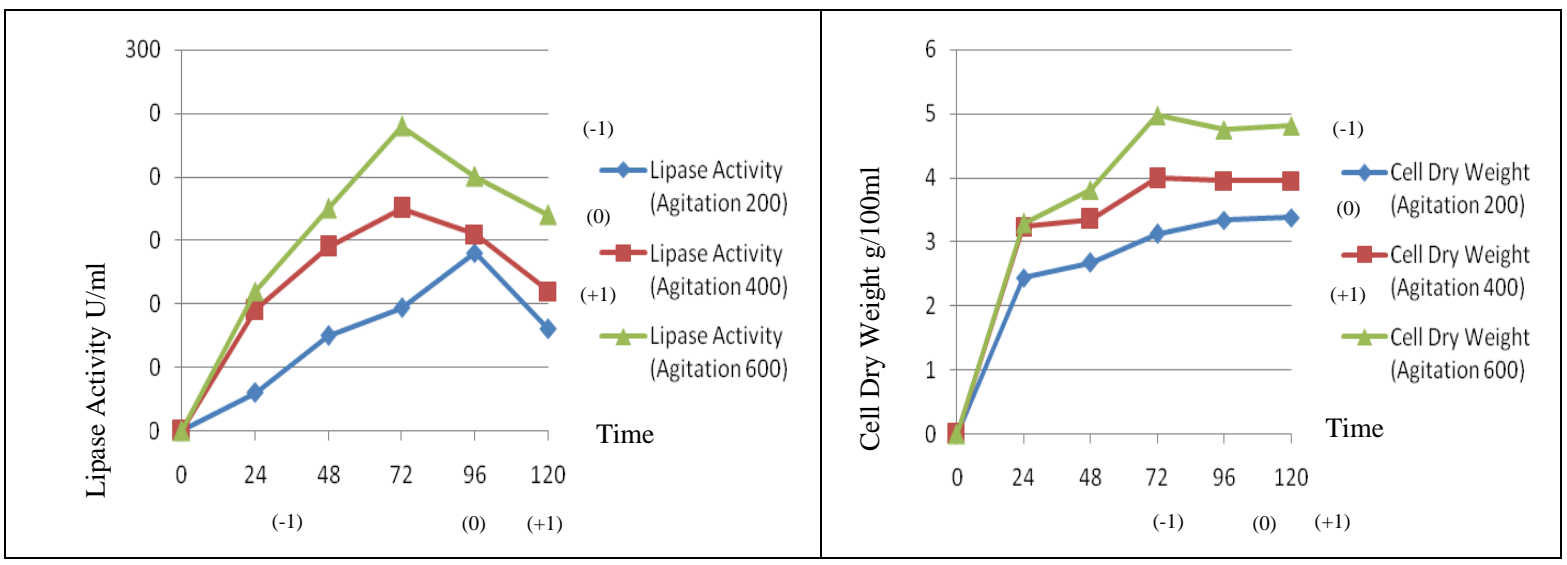

Figure 1: Time course of lipase production by $P$. chrysogenum under controlled aeration (2 L /min "-1").

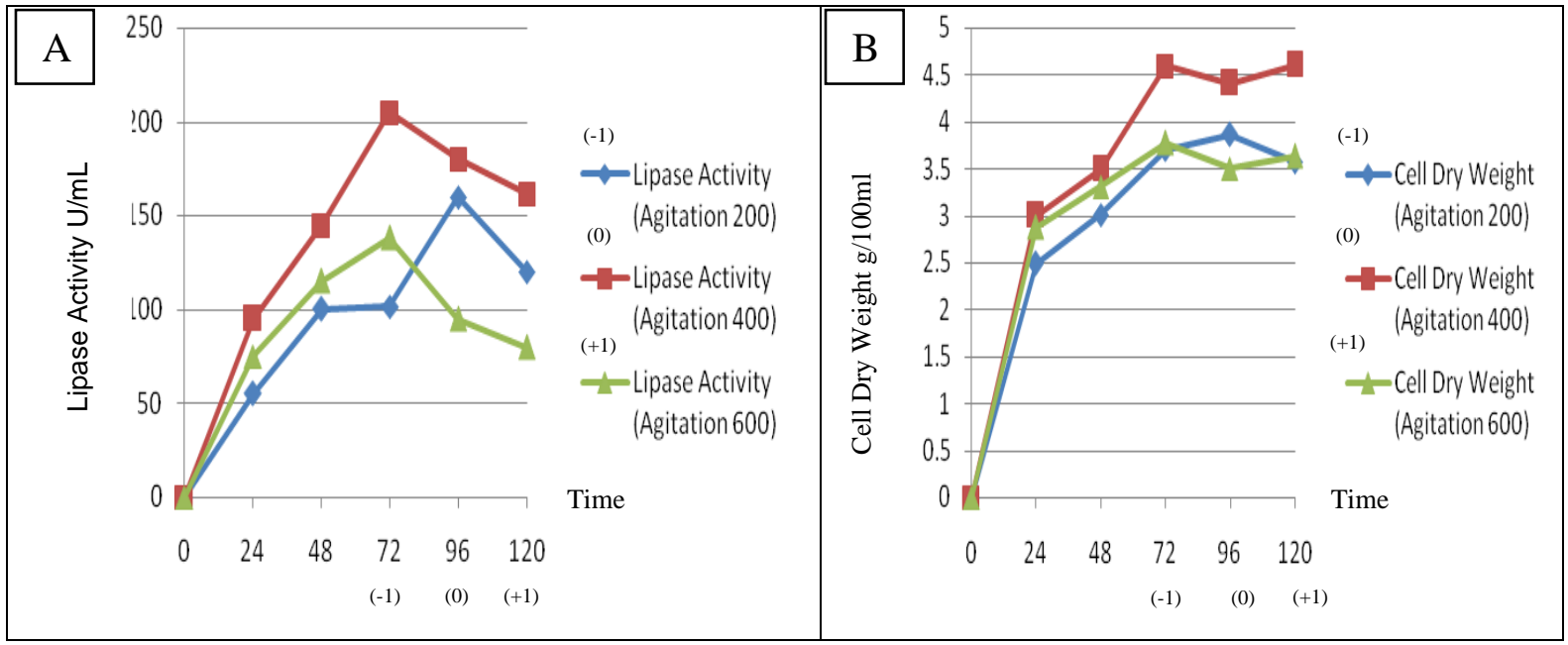

Figure 2 (A, B): Time course of lipase production by $P$. chrysogenum under controlled aeration (4L /min “1”). 
should be noted that at agitation speed $200 \mathrm{rpm}$, lipase production was maximum. When aeration increased from 200 to $600 \mathrm{rpm}$, the lipase production decreased. Similar results were obtained by Elibol and Ozer (2000) who reported that lipase production only occurred in the presence of air and, therefore, indicated that the critical demand of oxygen was higher for lipase production than for growth.

Figure 2 shows the growth curve and the lipase production at different agitation speeds (200, 400, 600 rpm) under controlled aeration (4.0 vvm). It can be observed that maximum lipase activity $(160 \mathrm{U} / \mathrm{mL})$ was obtained after $96 \mathrm{~h}$ at $200 \mathrm{rpm}$ and on increasing the agitation speed from 200 to $400 / \mathrm{rpm}$ the lipase activity was $205 \mathrm{U} / \mathrm{mL}$ at $72 \mathrm{~h}$. On increasing the agitation speed to $600 \mathrm{rpm}$ lipase activity decreased once more. This may be attributed to the fact that the degree of aeration is critical in some cases. Similarly Ebrahimpour et al. (2008) showed that shallow layer (static culture) where aeration is moderate produced much more lipase than shake cultures (high aeration).

\section{Analysis of variance (ANOVA) and adequacy test of the model}

Model coefficients, $F$ values and $P$ values, which were generated by the Design Expert software (2009), can be used to evaluate the model. If $p<0.05$, this indicates that the controllable factor or their interactions has a significant effect on the response factor (Amin and Anggaro, 2004; Zheng et al., 2009).

Tables 3 and 4 showed that the probabilities for the regression quadratic models of both lipase activity and cell dry weight were significant $(p<0.0001)$ and the lack of fits were insignificant $(p>0.05)$. This means that both models were statistically good, and the models had no lack of fit. The diagnostic examination for the residual revealed no violations of the ANOVA underlying assumptions, which mean that the ANOVA results can be trusted. Therefore, as indicated in Tables 3 and 4 , the fitted model is significant with a $p$ value of $<0.0001$.

The results indicated that the aeration, agitation, and the fermentation time with their interactions have a significant effect on the lipase activity. Higher orders of the controllable factors and the products of the controllable factors also have a significant effect on the lipase activity. With the exception of the fermentation time, the above factors also have a significant effect on the cell dry weight.

Table 3: Analysis of variance (ANOVA) for the lipase activity.

\begin{tabular}{llllll}
\hline Source & $\begin{array}{l}\text { Sum of } \\
\text { squares }\end{array}$ & DF & Mean square & F-value & $p$-value \\
\hline Model & 104863 & 9 & 11651.44 & 29.785 & $<0.0001$ \\
(A)-aeration & 5688.88 & 1 & 5688.88 & 14.54 & 0.0004 \\
(B)-Speed & 18.75 & 1 & 18.75 & 0.04 & 0.827 \\
(C)-Time & 13806.25 & 1 & 13806.25 & 35.29 & $<0.001$ \\
AB & 32700.69 & 1 & 32700.69 & 83.59 & $<0.0001$ \\
BC & 6337.5 & 1 & 6337.5 & 16.201 & $<0.0002$ \\
$B^{2}$ & 10305.79 & 1 & 10305.79 & 26.34 & $<0.0001$ \\
$C^{2}$ & 2750.23 & 1 & 2750.23 & 7.03 & 0.011 \\
AB & 16502.08 & 1 & 16502.08 & 42.18 & $<0.0001$ \\
BC & 7200 & 1 & 7200 & 18.40 & $<0.0001$ \\
Residual & 17211.57 & 44 & 391.17 & & \\
Lack of fit & 3394.90 & 8 & 424.36 & 1.10 & 0.382 \\
Pure Error & 13816.67 & 36 & 383.79 & & \\
$\mathrm{R}^{2}$ & 0.859 & & & & \\
Total & 122074.5 & 53 & & \\
\hline
\end{tabular}


Table 4: Analysis of variance (ANOVA) for the cell dry weight.

\begin{tabular}{llllll}
\hline Source & $\begin{array}{l}\text { Sum of } \\
\text { squares }\end{array}$ & DF & Mean square & F-value & $p$-value \\
\hline Model & 15.56 & 5 & 3.11 & 36.76 & $<0.0001$ \\
(A) Aeration & 1.45 & 1 & 1.42 & 17.13 & $<0.001$ \\
(B) speed & 4.98 & 1 & 4.98 & 58.89 & $<0.001$ \\
$\mathrm{AB}$ & 6.02 & 1 & 6.02 & 71.10 & $<0.001$ \\
$\mathrm{~B}^{2}$ & 1.73 & 1 & 1.73 & 20.44 & $<0.001$ \\
$\mathrm{AB}^{2}$ & 2.75 & 1 & 2.75 & 32.55 & $<0.0001$ \\
Residual & 4.06 & 48 & 0.08 & & \\
Lack of fit & 00 & 12 & 0.04 & 0.42 & \\
Pure error & 3.5 .56 & 36 & 0.098 & & \\
$\mathrm{R}^{2}$ & 0.80 & & & & \\
Total & 19.62 & 53 & & & \\
\hline
\end{tabular}

\section{Model fitting}

A model fitting was accomplished for the experiment based on the data shown in Table 2 below. The quadratic regression models were obtained by using coded values from the estimation of data was as follows:

Lipase activity $(\mathrm{U} / \mathrm{mL})=-983.2-70.3^{*} \mathrm{~A}+1.5{ }^{*} \mathrm{~S}+25.6$ ${ }^{*} \mathrm{~T}+0.6^{*} \mathrm{~A}^{*} \mathrm{~S}-0.05^{*} \mathrm{~S}^{*} \mathrm{~T}^{*}+2.0 \mathrm{E}-003 \mathrm{~S}^{*} \mathrm{~S}^{2}-0 . \mathrm{1}^{*} \mathrm{~T}^{2}-$ ............................Eq. (1)

Cell dry weight $(\mathrm{g} / 100 \mathrm{~mL})=4.4-0.8^{*} \mathrm{~A}-0.01^{*} \mathrm{~S}+$ $7.5 \mathrm{E}-003^{*} \mathrm{~A}^{*} \mathrm{~S}+2.6 \mathrm{E}-005^{*} \mathrm{~S}^{2}$ $-1.2 E-005 * A^{*} S^{2} \ldots \ldots \ldots \ldots \ldots \ldots \ldots \ldots \ldots \ldots . \ldots q .(2)$

Where $A, S$ and $T$ represents aeration, agitation and fermentation time respectively. Utilizing Eq. (1), the lipase activity can be estimated for any combination of the controllable factors (aeration, speed and time). It may be worth saying that Eq. (1) and (2) could be used only if the aeration is between 2 and $4 \mathrm{vvm}$, the agitation is between 200 and 600 rpm and fermentation time is between 72 and $120 \mathrm{~h}$. Model Eq. (1) reports a coefficient of determination $R^{2}$ of 0.8590 which implies that the model can explain $86 \%$ of the variation in the lipase activity. The values of the adjusted $R^{2}$ and the adequate precision are 0.8302 and 20.039 respectively. Both values indicated that the model can be used to navigate the design space and that the model fitness is very good. Similarly the fitted regression model that describes the cell dry weight is shown in Eq. (2). This model reveals $R^{2}$ equal to 0.8 meaning that the fitted model explains $80 \%$ of the variability in the cell dry weight. It should be noted that a model can be considered predictive if the coefficient of determination $\left(R^{2}\right)$ is close to 1.0 (Gutarra et al., 2009)

The data were fitted to the response surface model to effectively evaluate the true relationship between the lipase activity/cell dry weight and the controllable factors. These investigations are based upon the optimization of cultural conditions for the lipase production and cell dry weight. The optimization was observed by varying three factors: aeration, speed and fermentation time with their respective levels shown in
Table 2. The aeration was tested at 2 levels ( 2 and 4 vvm), agitation was tested at 3 levels $(200,400,600$ $\mathrm{rpm})$. The experiment was performed at 3 different fermentation periods $(72,96$ and $120 \mathrm{~h}$ ) to find the optimum combination of these factors that maximizes the lipase activity as well as the cell dry weight. Eq. (1) and (2) were chosen to fit the experimental data for lipase activity $(\mathrm{U} / \mathrm{mL})$ and the cell dry weight (mg/100mL).

\section{Response Surfaces Methodolgy (RSM)}

In order to study the effects of the three factors as well as their interaction on lipase activity response surfaces and contour plots are generated as shown in Figure 3. It denotes the three dimensional response surface plots of agitation and aeration on lipase activity of $P$. chrysogenum generated at $72 \mathrm{~h}$ fermentation time (found to produce the highest lipase activity). As can be seen, enhancing the agitation from 200 to $600 \mathrm{rpm}$ could increase the lipase activity while the aeration must be kept at 2 vvm. However the lipase activity decreased by further increasing the aeration and decreasing agitation. As indicated, higher agitation and lower aeration were more favorable for improving lipase activity. This may be attributed to the fact that variation in agitation results in a change in oxygen transfer rate, which in turn affected the rate and extent of cell growth and lipase production (Elibol and Ozer, 2004). It should be noted that agitation accelerates oil hydrolysis (Hwan et al., 2007). On the contrary, static condition had resulted in comparatively high lipase production for Syncephalastrum racemosum (Chopra and Chander, 1983), Pseudomonas sp. strain S5 (Rahman et al., 2006) and Pseudomonas aeruginosa (Nadkarni, 1971). Generally, suitable agitation leads to sufficient supply of dissolved oxygen in the media (Kumar and Takagi, 1999).

The coded model shown in Eq. 2 is used to generate the response surface shown in Figure 4 assists the analysis of the effect of the controllable factors on the cell dry weight. Figure 4 showed that on increasing the speed of agitation to $600 \mathrm{rpm}$ and 


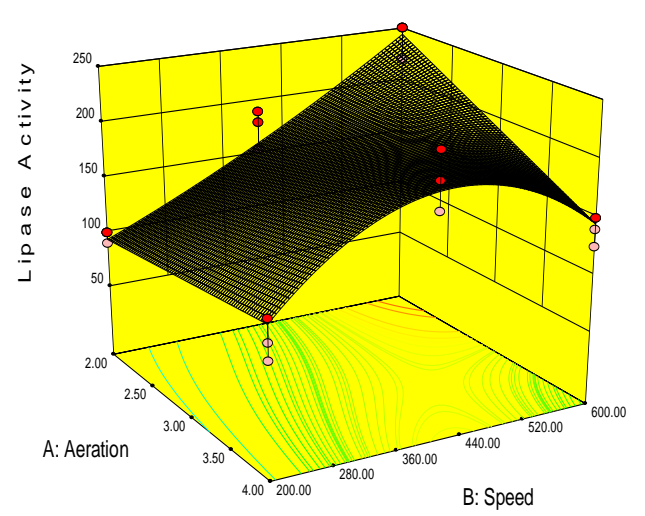

Figure 3: Response surface for the lipase activity of $P$. chrysogenum after $72 \mathrm{~h}$ of fermentation time.

reducing aeration to $2 \mathrm{vvm}$ lead to a suitable growth after $72 \mathrm{~h}$ which in turn showed maximum lipase activity. Hoffman and Cleffman (1981) noticed that higher dissolved oxygen concentration in the medium did not significantly improve cell density. However, an increased biomass was obtained when aeration was 2 vvm. In the same way, aeration and agitation were previously found to influence growth and protease production (DeConink et al., 2000 and 2004).

\section{Model optimization}

According to the discussion above, it is possible to obtain high lipase activity using $P$. chrysogenum and a suitable cell dry weight through searching for the optimum point. Non-linear optimization was used to find the optimum value for aeration, speed and fermentation time that will express high lipase activity and cell dry weight simultaneously. The optimization model shows that aeration should be kept at a lower level of 2; the speed should be higher level of 600 while the fermentation time should be $72 \mathrm{~h}$.

However, it was found out that at different levels of relative importance, the maximum values of the response factors did not change. There is also high positive correlation between the lipase activity and the cell dry weight which was found to be equal to 0.815693.The experimental values $(240 \mathrm{U} / \mathrm{mL}$ for lipase activity and $4.810 \mathrm{~g} / 100 \mathrm{~mL}$ for cell dry weight) were in agreement to the predicted ones $(244.12 \mathrm{U} / \mathrm{mL}$ for lipase activity and $4.8464 \mathrm{~g} / 100 \mathrm{~mL}$ for cell dry weight). This confirmed the validity and adequacy of the predicted models.

\section{CONCLUSION}

In this study, RSM was successfully applied to determine the influential factors that lead to maximum lipase activity/cell dry weight of $P$. chrysogenum. Two

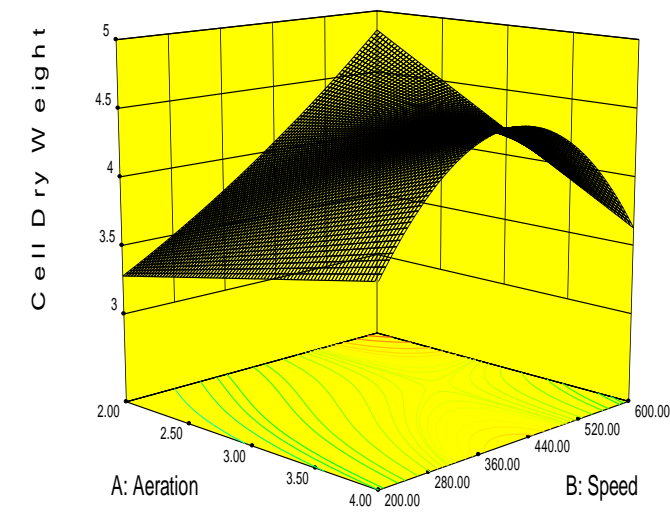

Figure 4: Response surface for the cell dry weight of $P$. chrysogenum.

sets of quadratic model were obtained to describe the relationship between the parameters (aeration, agitation and fermentation time) and responses (lipase activity and cell dry weight). Two response surface plots and two contour plots were used to analyze the conditions for the maximum lipase activity and cell dry weight. Furthermore, under optimized conditions the experimental values agreed well with the predicted data. The optimal experimental conditions from this design allowed a fast, quantitative and maximum lipase activity. The results from these experiments could contribute to the development and use of this system on industrial scale.

\section{REFERENCES}

Amin, N. A. S. and Anggaro, D. D. (2004). Optimization of direct conversion of methane to liquid fuels over $\mathrm{Cu}$ loaded W/Z SM-5 catalyst. Fuel 83, 487-498.

Burkert, J. F. M., Maugeri, F. and Rodrigues, M. I. (2004). Optimization of extracllular lipase production by Geotrichum sp. using factorial design. Bioresource Technology 91, 77-84.

Cammarota, M. C. and Freire, D. M. G.(2006). A review on hydrolytic enzymes in the treatment of wastewater with high oil and grease content. Bioresource Technology 97, 2195-2210.

Chen,J. Y., Wen, C. M. and Chen, T. C.(1999). Effect of oxygen transfer on lipase production by Acinetobacter radioresistens .Biotechnology Bioengineering 62, 311-316.

Chopra , A. K. and Chander, H. (1983). Factors affecting lipase production in Syncephalastrum racemosum. Journal of Applied Bacteriology 54,163-169.

Cihangir, N. E. and Sarikaya, E. (2004). Investigation of lipase production by a new isolate of Aspergillus 
sp. World Journal of Microbiology Biotechnology 20, 193-197.

DeConink, J., Leclercq, B., Exbrayat, M. J. and Duyme, F.(2004). Factorial design: An efficient approach to choosing the main factors influencing growth and hydrolase production by Tetrahymena thermophila. Journal of Indian Microbiology Biotechnology 31, 204-208.

DeConink, J., Verdier-Denantes, I., Duyme, F., Bouquelet, S. and Dumortier, V. (2000). Modeling Tetrahymena thermophila growth and protease production. Journal of Indian Microbiology Biotechnology 25, 57-61.

Design Expert Software Version 8.0.0, Statease Corporation(2009).

Ebrahimpuor, A., Rahman, R., EanChing, D. and Salleh, A. (2008). A modeling study by response surface methodology and artificial neural network on culture parameters optimization for thermostable lipase production from a newly isolated thermophilic Geobacillus sp. Strain ARM. BMC Biotechnology 8, 96-111.

Elibol, M. and Ozer, D. (2000). Influence of oxygen transfer on lipase production by Rhizopus arrhizus. Process Biochemistry 36, 325-329.

Frost, G. M. and Moss, D. A. (1987). Production of enzymes by fermentation. In: Biotechnology. Rehm, H. J. and Reed, G. W. (eds.). VCH VerlagsgessellschaftmbH Germany, 7a, 65-211.

Garrido-Vidal, D., Pizarro, C. and Gonzalez-Saiz, J. M. (2003). Study of process variables in industrial acetic fermentation by a continuous pilot fermentor and response surfaces. Biotechnology Program 19, 1468-1479.

Gutarra, M. L. E., Godoy, M. G., Maugeri, F., Rodrigues, M. I., Freire, D. M. G. and Castilho, L. R. (2009). Production of an acidic and thermostable lipase of the mesophilicfungus Penicillium simplicissium by solid state fermentation. Bioresource Technology 100, 52495254.

Hoffmann, E. and Cleffman, G. (1981). External factors limiting the multiplication. Potential of Tetrahymena. Journal of Cell Science 50,407-418.

Hölker, U., Höfer, M. and Lenz, J. (2004). Biotechnological advantages of laboratory- scale solid state fermentation with fungi. Applied Microbiology Biotechnology 64, 175-186.

Hwan, L. D., Kim, J. M., Shin, H. Y. and Kim, S. W. (2007). Optimization of lipase pretreatment prior to lipase immobilization to prevent loss of activity. Journal of Microbiology Biotechnology 17(4), 650654.

Javed, M. M., Khan, T. S. and UI-Haq, I.(2007). A $2^{3}$ level full factorial design to optimize cultural conditions for lipase production by consortium of Aspergillus niger and Trichoderma viride. Research Journal of Microbiology 2 (8), 639-644.

Kamimura, E. S, Medieta, O., Rodrigues, M. I. and Maugeri, F. (2000). Studies on lipase affinity adsorption using response - surface analysis. Biotechnology Applied Biochemistry 33, 153-159.

Kamini, N. R., Fujii, T., Kurosu, T. and Lefuji, H.(2000). Production, purification and characterization of an extracellular lipase from yeast Coryptococcus sp. S2. Process Biochemistry 33, 153 -159.

Kumar, C. G. and Takagi, H. (1999). Microbial alkaline proteases from a bioindustial viewpoint. Biotechnology Advances 17, 561-594.

Lee, S. Y. and Rhee, J. S.(1993). Production and partial purification of lipase from Pseudomonas putida. Enzyme Microbiology Biotechnology 15, 617-623.

Lima, V. M. G., Krieger, N. Sarquis, M. I. M., Mitchell, D. A., Ramos, L. P. and Fontana, J. D. (2003). Effect of nitrogen and carbon sources on lipase production by Penicillium aurantigoriseum. Food Technology Biotechnology 41, 105-110.

Mutalik, S. R., Vaidya, B. K., Joshi, R. M., Desai, K. M. and Nene, S. N.(2008). Use of response surface optimization for the production of biosurfactant from Rhodococcus spp. MTCC 2574. Bioresource Technology 99, 7875-7880.

Nadkarni, S. R. (1971). Studies on bacterial lipase. II. Study of the characteristics of partially purified lipase from Pseudomonas aeruginosa. Enzymologia 40, 286-301.

Nemukula, A., Mutanda, T., Wilhelmi, B. S. and Whiteley, C. G. (2009). Response surface methodology synthesis of short chain fractooligosaccharides with a fructosyltransferase from Aspergillus oculeatus. Bioresource Technology 100, 2040-2045.

Parry, R. M., Chandan, R. C. and Shahani, K. M.(1966). Rapid and sensitive assay for milk lipase. Journal of Dairy Science 49, 356-360.

Rahman, R., Baharum, S. N., Salleh, A. B. and Basri, M. (2006). S5 lipase: An organic solvent tolerant enzyme. Journal of Microbiology 44, 583-590.

Sharma, R., Chisti, Y. and Banerjee, U. C. (2001).Production, purification, characterization and application of lipases. Biotechnology Advances 19, 627-662.

Vadehra, D. A. and Harmos, L. G.(1969). Factors affecting production of Straphylococcol lipase. Journal of Applied Bacteriology 32, 147-150.

Zheng, Y., Wu, X. M., Branford-white, C., Quan, J. and Zhu-Li, M. (2009). Dual response surfaceoptimized process for feruloylated diacylglycerols by selective lipase. Catalysed transestesification in solvent free system. Bioresource Technology 100, 2896-2901. 